\title{
ENZYMATIC ENHANCEMENT OF THE FREE MONOTERPENOL CONTENT OF A PORTUGUESE WINE FROM A SINGLE, NATIVE GRAPE VARIETY; "TRAJADURA".
}

\author{
F.S.S.ROGERSON ; H.J.GRANDE ; M.C.M.SILVA* \\ Universidade Católica/Escola Superior de Biotecnologia. \\ Rua Dr.Antonio Bernardino de Almeida, 4200 Porto. Portugal.
}

\section{SUMMARY}

Three important monoterpene aroma releasing activities contained in an Aspergillus niger preparation were investigated for effects of $\mathrm{pH}$, alcohol, $\mathrm{SO}_{2}$, temperature and concentration of glucose. Application of the enzyme preparation during microvinification or wine maturation of a Portuguese white wine from "Trajadura" grapes, increased monoterpene content roughly 2 -fold and 3 -fold respectively .

\footnotetext{
ABBREVIATIONS

$\alpha$-L-araf - $\alpha$-L-arabinof uranosidase ; $\alpha$-L-rhap - $\alpha$-L-rhamnopyranosidase ; $\beta$-D-glup - $\beta$ D-glucopyranosidase ; pnp - p-nitrophenyl.
}

\section{INTRODUCTION}

Monoterpenes are, in general, important aroma constituents of grapes and wine. More than 50 compounds are known (Rapp, 1987), these include linalool, $\alpha$-terpineol, citronellol, nerol and geraniol which in conjunction give muscat grapes and wine their characteristic floral fragrances (Bayonove \& Cordonnier, 1971 ; Ribereau-Gayon,P et al., 1975). Such compounds are also important aromatic constituents of the cultivars Gewürztraminer and Riesling (Schreier et al., 1976; Schreier et al., 1977 ; Marais \& van Wyk, 1986 ; Marais, 1987).

Portuguese grape varieties have been little studied, although Andrade et al. (1990) investigated the quantities of linalool, $\alpha$-terpineol, citronellol, nerol and geraniol in musts from the "vinho verde" cultivars "Loureiro", "Pedernã" and "Trajadura" by ether/hexane cxtraction and glass capillary gas chromatography (GCGC); the authors found only citronellol present, emphasising the neutrality of the varieties.

This latter conclusion, indicating aromatic neutrality needs to be investigated further since recent work by Gucdes de Pinho (1991) and Rogerson \& Silva (1994) has shown wine from the cultivar "Lourciro" to contain linalool at levels around its minimum threshold

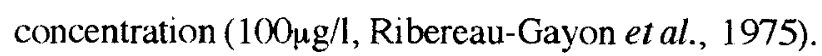

Grape monoterpenols also exist in an odourless bound form, glycosidically linked to $\beta-\mathrm{D}$ glucose which is in turn linked to one of the sugars $\alpha$-L-rhamnose, $\alpha$-L-arabinofuranose or $\beta$-apiose (Williams et al., 1982 ; Brillouet et al., 1989). In the case of muscat monoterpene aroma, upto $90 \%$ has been shown to occur in this bound form (Park et al., 
1991). The bound monoterpene alcohols can be released by specific glycosidases or by acid hydrolysis.

Natural enzyme activities originating from the grape or present in the fermentation yeasts are capable of cleaving the sugars releasing aroma, however, further aroma enhancement can be achieved by application of exogeneous enzymes with $\alpha$-L-arap, $\alpha$-L-rhap, $\beta$-Dglup and $\beta$-apiosidase activities (Gunata et al., 1988 ; Voirin et al., 1990).

Pectinases are commonly used for wine and fruit juice maceration and/or clarification (Pilnik, 1982); such commercial enzyme preparations contain many monoterpene aroma releasing activities which are capable of enhancing aroma during wine-making (Versini et al., 1981 ; Cordonnier et al., 1989).

Further details concerning enzymes in wine-making, including the application of enzyme preparations containing specific glycosidases for the enhancement of free aromatic monoterpene alcohols can be found in two recent reviews (Canal-Llauberes, 1993 ; Colagrande etal., 1994).

The objectives of this present study were to investigate an experimental enzyme preparation derived from Aspergillus niger : (i) focusing on three important glycosidase activities present ( $\alpha$-L-araf, $\alpha$-L-rhap, $\beta$-D-glup), determining the effect of $\mathrm{pH}, \mathrm{SO}_{2}$, temperature, ethanol concentration and glucose concentration on their activities; (ii) evaluating its application during the microvinification and maturation of a wine made from a single grape variety.

\section{MATERIALS AND METHODS}

"Trajadura" grapes were obtained from the vineyards of Borges \& Irmão in Lixa, northern Portugal.

The experimental Aspergillus niger enzyme preparation and the Saccharomyces cerevisiae Yeast, "Firmivin" were from Gist Brocades, France.

Substrates investigated were $p$ np- $\alpha$-L-arabinofuranoside, $p$ np- $\alpha$-L-rhamnopyranoside and pnp- $\beta$-D-glucopyranoside from Sigma.

All other substances were research grade.

Enzyme activity measurements are expressed in International Units (U). Enzyme protein was assayed by the method of Sedmak \& Grossberg (1977), using bovine serum albumin as standard.

The glycosidase activities were determined by measuring the amount of $p$-nitrophenol released from the synthetic substrate according to the method of Rombouts et al (1988). Enzyme incubation was carried out in $30 \mathrm{mM}$ tartaric acid buffer $\mathrm{pH} 3.5$ at $20^{\circ} \mathrm{C}$ for either 1 or 24 hours depending upon the substrate. Activity variation with $\mathrm{pH}$ used a range of buffers with $30 \mathrm{mM}$ concentration:- phosphoric acid $\mathrm{pH} 2.0 ; 2.5 ;$ tartaric acid $\mathrm{pH} 3.0$; 3,$5 ; 4.0$; acetate $\mathrm{pH} 4.5,5.0,5,5 ;$ citrate $\mathrm{pH} 6.0,6.5$ and phosphate $\mathrm{pH} 7.0$ \& 7.5.

All other investigations used a $30 \mathrm{mM}$ tartaric acid, $\mathrm{pH} 3.5$ buffer which was adapted to have either:

-Ethanol concentration between 0 and $20 \% \mathrm{v} / \mathrm{v}$.

$-\mathrm{SO}_{2}$ concentration between $\mathrm{O}$ and $200 \mathrm{mg} / \mathrm{l}$.

-Glucose concentration between 0 and $100 \mathrm{~g} / \mathrm{l}$.

Enzymic activity variation with temperature used a $30 \mathrm{mM}$ tartaric acid buffer, $\mathrm{pH} 3.0$, with incubations at $11^{\circ} \mathrm{C}, 18^{\circ} \mathrm{C}, 25^{\circ} \mathrm{C} \& 30^{\circ} \mathrm{C}$.

The free aromatic terpene alcohols were extracted from $50 \mathrm{ml}$ of neutralised wine, containing the internal standard 2-ethylhexanol, into pentane/ether $(80: 20) 3 \mathrm{ml}+1 \mathrm{ml}+1 \mathrm{ml}$ and analysed by quantitative GCGC analysis using a Hewlett Packard gas chromatograph 
model 5890 containing a WCOT fused silica capillary column from Chrompack CPWAX $-57 \mathrm{CB}(50 \mathrm{~m}$ long $\times 0.25 \mathrm{~mm}$ internal diameter) with FID detector and helium as carrier gas $(1 \mathrm{ml} / \mathrm{min})$. Injection mode $(1 \mu \mathrm{l})$ was splitless $(1: 30)$ and peak identification was based on peak retention time using the internal standard as reference. Injector and detector temperatures were both $250^{\circ} \mathrm{C}$. Peak separation used the following temperature gradient program: $60^{\circ} \mathrm{C}$ for 10 minutes, $2.5^{\circ} \mathrm{C}$ rise per minute until $200^{\circ} \mathrm{C}$, with finally 24 minutes at $200^{\circ} \mathrm{C}$. Peak integration used a Hewlett Packard Model HP3390A.

Microvinification was carried out as indicated by the flow chart given in figure 1 . The grape must was obtained from a single batch of pressed, sulphited $(30 \mathrm{mg} / \mathrm{L})$ "Trajadura" grapes.

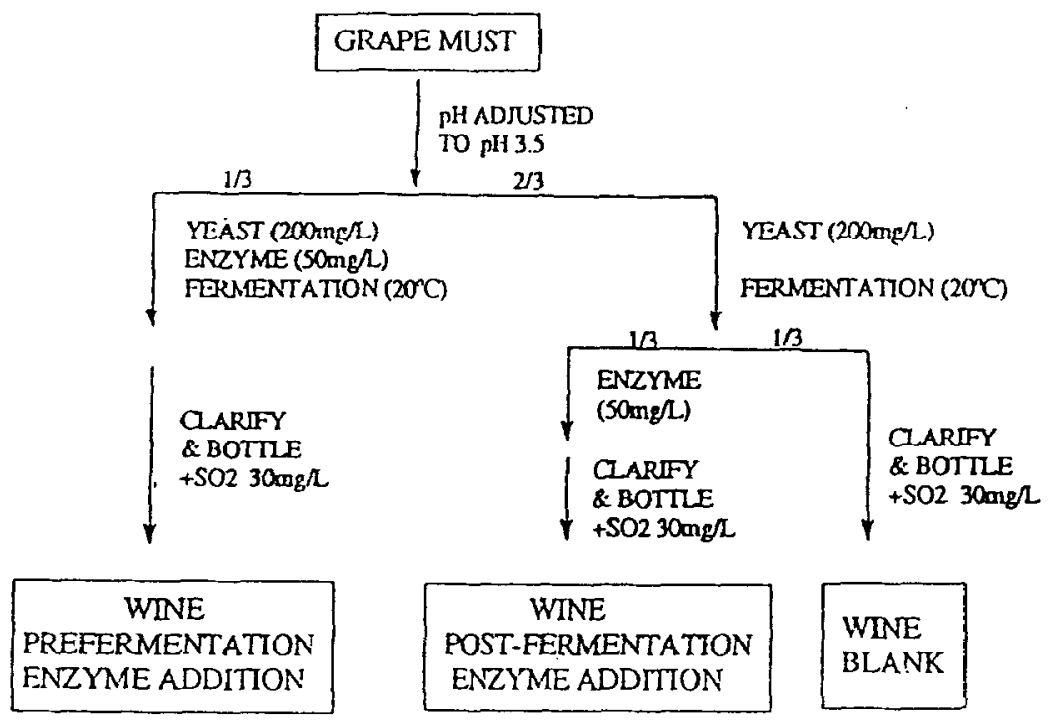

Figure 1 - Microvinification Procedure.

RESULTS AND DISCUSSION

Enzyme Characterisation

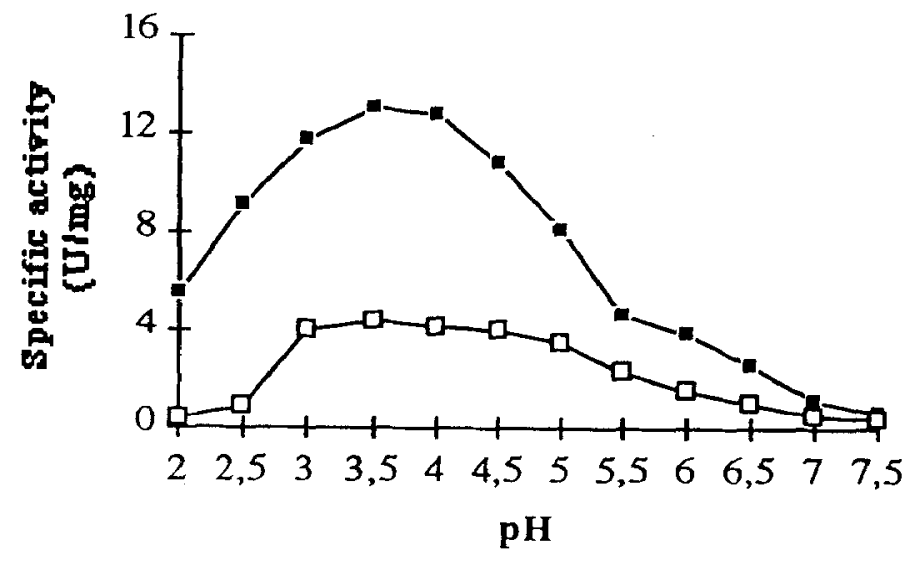

Figure 2 -Effect of $\mathrm{pH}$ on $\alpha$-L-araf ( $(\mathbf{a})$ and $\beta$-D-glup (u) activities. 


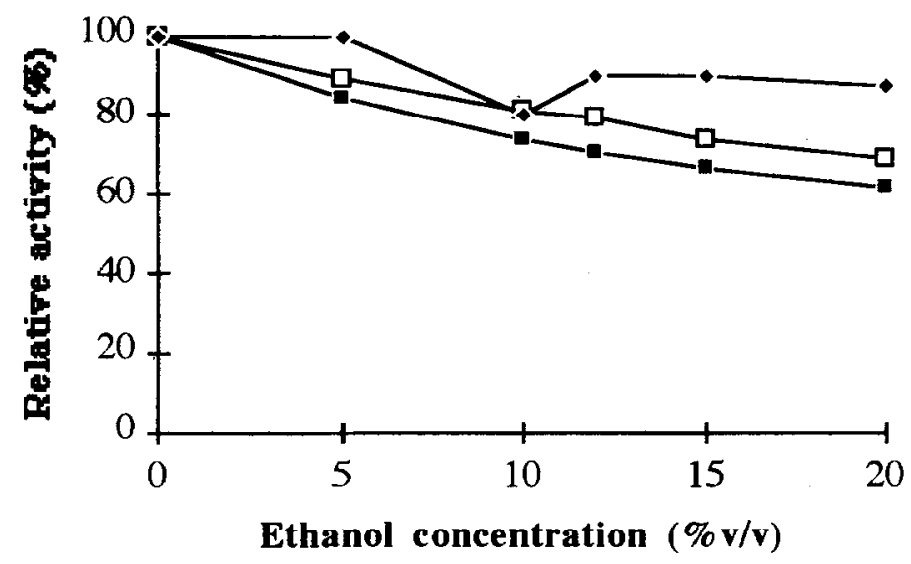

Figure 3 - Effect of ethanol on $\alpha$-L-araf ( $\square$ ), $\beta$-D-glup ( $(\square)$ and $\alpha$-L-rhap ( $\bullet$ ) activitics.

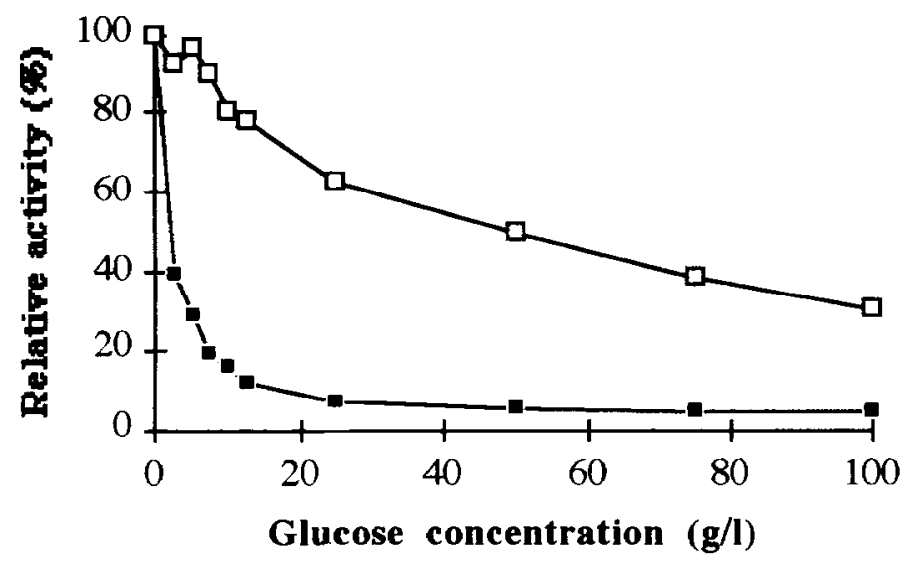

Figure 4 - Effect of glucose concentration on $\beta$-D-glup ( $\mathbf{(})$ and $\alpha$-L-rhap (ם) activities.

The three important glycosidases were examined over $\mathrm{pH}$ range 2.0 to 7.5 . Optimum $\mathrm{pH}$ for $\alpha$-L-arap and $\beta$-D-glup were both around 3.5 (figure 2), whereas the $\alpha$-L-rhap gave maximum specific activity of $0.109 \mathrm{U} / \mathrm{mg}$ protein at $\mathrm{pH} 5.5$ (data not shown), approximately 120 times lower than the $\alpha$-L-arap.

$\mathrm{SO}_{2}$ had no effect on the three activities tested up to a concentration of $200 \mathrm{mg} / \mathrm{l}$ (data not presented). Ethanol, at wine related concentrations $(10 \% \mathrm{v} / \mathrm{v})$, gave a reduction in activity by up to $25 \%$ (figure 3 ).

The $\alpha$-L-arap activity was not affected by the presence of glucose (data not presented); however, both the $\alpha$-L-rhap and $\beta$-D-glup activities were; the latter being greatly reduced (figure 4). Glucose levels such as typically present in grape must $(100 \mathrm{~g} / \mathrm{l})$ would almost completely diminish the $\beta$-D-glup activity. This finding is in accordance with the results of Gunata et al., (1992). 
Activities measured over a range of typical temperatures encountered in wine-making, roughly doubled for an increase of $10^{\circ} \mathrm{C}$. This figure agrees with literature data (Godfrey \& Reichett, 1983).

\section{Application of the Aspergillus niger Preparation}

The enzyme preparation was examined during the microvinification of "Trajadura" grapes (figure 1). The grape must was partially de-acidified to $\mathrm{pH} 3.5$ before fermentation and enzyme addition, so that the activities in the preparation would have maximum effect.

Table1 - Enzymic enhancement of free monoterpenols in a single cultivar "vinho verde" wine,"Trajadura". - Examination after 2 months maturation in bottle $(\mu \mathrm{g} / \mathrm{l})$.

\begin{tabular}{|l|l|l|l|l|l|l|}
\hline Sample & Linalool & $\alpha$-Termineol & Citronellol & Nerol & Geraniol & Total \\
\hline Blank & 17.2 & 3.6 & 45.3 & 8.1 & 25.7 & 99.9 \\
\hline Pre-Ferment & 22.8 & 33.6 & 49.2 & 15.2 & 42.9 & 163.7 \\
\hline Post-Ferment & 31.1 & 67.5 & 40.2 & 17.0 & 77.5 & 233.3 \\
\hline
\end{tabular}

The results clearly indicate that free monoterpene levels can be enhanced in this wine by application of the experimental Aspergillus niger enzyme preparation (table 1). The postfermentation enzyme addition gave the largest increase in total free monotcrpenes, roughly three times that of the blank wine. This result is not unexpected, considering the data oblained on the characterisation of the enzymes, which show $\beta$-D-glucosidase to be inhibited by glucose (figure 4). The mechanisms of monoterpene release involves initial cleavage of an apiose, rhamnose or arabinofuranose sugar followed by sequential cleavage of a glucose (Gunata et al., 1988). The glucosidase activity being the most important since it cleaves the ultimate sugar.

This experiment applied the enzyme preparation to grape must which had been partially de-acidified to $\mathrm{pH}$ 3.5. Andrade et al. (1990) reported that "vinho verde" musts would be too acidic for effective monoterpene release by application of specific glycosidases. This work shows that such enzyme preparations are capable of monoterpene release in young "vinho verde" wines fermented from partially de-acidified musts. The characterisation data also suggests that this particular enzyme preparation would be cffective if applied to wines fermented from non-neutralised musts, with $\mathrm{pH}$ 3.0. 


\section{ACKNOWLEDGEMENTS}

This work was supported by "Programa Ciencia" a grant from the "Junta Nacional de Investigação Cientifica e Tecnológica". The Authors also express their thanks to Dr. L.Le Chevanton of Gist-Brocades, France for providing the Aspergillus niger enzyme preparation and the Saccharomyces cerevisiae yeast and to Dr. R.Albergaria of Borges \& Irmão for providing the grapes from their vineyards in "Lixa".

\section{REFERENCES}

Andrade,M.A., Freitas,A.M., \& Maia,M.O.(1990). V. Congresso Nacional de Biotecnologia - Universidade do Minho. Portugal.

Bayonove,C., \& Cordonnier,R. (1971). Ann.Technol.Agric. 20(4), 347-355.

Brillouet,J.M., Gunata,Z., Bitteur,S., Cordonnier,R., \& Bosso,C. (1989). J.Agric.Food.Chem. 37, 910-912.

Canal-Llaubcres,R-M. In "Winc Microbiology and Biotcchnology". Chapter 17, 477506. Edited by Fleet,G.H., Publishers Harwood Academic Press.

Colagrande,O., Silva,A., \& Fumi,M.D. (1994). Biotechnol.Prog. 10, 2-18.

Cordonnier,R.E., Gunata,Y.Z., Baumes,R.L., \& Bayonove,C.L. (1989). Connaissance de la Vigne et du Vin, Journal International des Sciences de la Vigne et du Vin. 23(1), 7 23.

Godfrey,T. \& Reichett,J. (Eds.) (1983). In "Industrial Enzymology - The Application of Enzymes in Industry".6.

Guedes de Pinho,M.P. (1991). Diplome d'etudes approfondies en oenologie-ampelolgic. Universite de Bordcaux II, Institut d'oenologie. Octobre 1991.

Gunata,Y.Z., Bitteur,S., Brillouet,J.M., Bayonove,C.L., \& Cordonnier,R. (1988). J.Chromatog. 184, 139-149.

Gunata,Z., Dugelay,I., Sapis,J.C., Baumes,R., \& Bayonove,C. (1992). International symposium of flavours precursors. University of Wurzburg, Germany. SeptemberOctober 1992.

Marais,J. \& van Wyk,C.J. (1986). S.Afr.J.Enol.Vitic.7(1), 26-35.

Marais,J. (1987). Vitis. 26, 231-245.

Park,S.K., Morrison,J.C., Adams,D.O., \& Noble,A.C. (1991). J. Agric.Food Chem. 39, 514-518.

Pilnik,W. (1982). In "Use of enzyme in food technology", 425-450. Paris: Technique et Documentation Lavoisier.

Rapp,A. (1987). In "Frontiers of flavour, proceedings of the 5th conference" Porto Karras, Chaldiki, Greece. 1-3 July 1987, 799-813. Charalambous, G (Editor), Elsevier Science Publishers.

Ribereau-Gayon,P., Boidron,J.N., \& Terrier,A. (1975). J.Agric.Food Chem. 23(6), $1042-47$.

Rogerson,F.S.S. \& Silva,M.C.M. (1994). Free communication. "I Congresso Internacional de la Vitivinicultura Atlántica". Isla de la Toja, Pontevedra, Galicia, España. 15-19 Mayo.

Rombouts,F.M., Voragen,A.G.J., Serle-van Leeuwen,M.F., Geraeds,C.C.J.M., Schols,H.A., \& Pilnik,W. (1988). Carbohydrate Polymers 9, 25-47.

Schreier,P., Drawert,F., \& Junker,A. (1976). Chem.Mikrobiol.Technol.Lebensm. 4, 154-157.

Schreier,P., Drawert,F., \& Junker,A. (1977). Chem.Mikrobiol.Technol.Lebensm. 5, 45-52.

Sedmak,J.J., \& Grossberg,S.E. (1977). Analytical Biochemistry 79, 544-552.

Versini,G., Inama,S., \& Sartori,G. (1981). Vini.Ital. 23, 189-211.

Voirin,S., Baumes,R.L., Bitteur,S., Gunata,Z.Y., \& Bayonove,C.L. (1990). J.Agric.Food Chem. 38, 1373-78.

Williams,P.J., Strauss,C.R., Wilson,B., \& Massy-Westropp,R.A. (1982). Phytochem., 21(8), 2013-20. 